
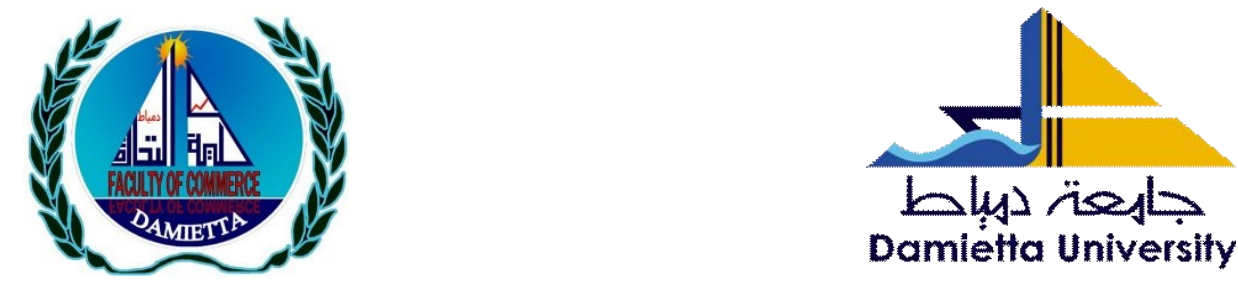

\title{
The Joint Impact of Transparency and Board Structure on Cost of Equity Capital: An Empirical Study on Companies Listed on Egyptian Stock Exchange
}

\author{
Prepared by \\ Dr. Mawaheb Abdel-Aziz Ismail \\ Accounting Lecturer \\ Faculty of Commerce, Alexandria University \\ mawaheb.ismail@comm.alexu.eg \\ mawaheb.ismail@gmail.com
}

Scientific Journal for Financial and Commercial Studies and Researches (SJFCSR)

Faculty of Commerce - Damietta University

Vol.2, No.1, Part 1., Jan. 2021

\section{APA Citation:}

Ismail, M. A. (2021). The Joint Impact of Transparency and Board Structure on Cost of Equity Capital: An Empirical Study on Companies Listed on Egyptian Stock Exchange. Scientific Journal for Financial and Commercial Studies and Researches (SJFCSR), Vol.2 (1) Part1. pp. 127- 181.

Website: https://cfdj.journals.ekb.eg/ 


\begin{abstract}
:
The paper examines the joint impact of transparency and board structure on cost of capital for a sample of firms listed on the Egyptian Stock Exchange during the period from 2010 through 2017. I predict that transparency and Board of Directors (BOD) structure has an impact of lowering cost of equity capital. The paper hypothesized that an interaction effect may exist between transparency and BOD structure in shaping their relationship with cost of capital. Results reveal that transparency has a negligible effect on cost of capital; on the contrary, evidence supports the positive impact of BOD governance on lowering cost of capital. Further, results uncover a complementary insignificant relationship between transparency and BOD structure.
\end{abstract}

Keywords: Cost of capital, corporate governance, timeliness, conservatism, transparency, board size, independence, audit committee, CEO duality. 


\section{INTRODUCTION}

For financial markets to undertake its role in promoting economic growth, businesses and investors should be able to evaluate all investment opportunities. The cost of capital metric is used by firms to internally judge the worthiness of a project compared to expenditure of resources, and by investors to determine the worthiness of an investment risk compared to return. In other words, cost of capital helps in assessing the investment options, by converting future cash flows of investment to its present value, thereby helps in capital budgeting decisions regarding the sources of finance used by the company. Conceptually, cost of capital is the average rate of return required by long term funds providers, or the minimum rate of return a firm must earn on its investment to maintain its market value of equity (Brealey et al. 2007).

For decades the concept of cost of capital has attracted the attention of researchers and academicians. A voluminous body of research has been devoted to examine the determinants of cost of capital, or the factors affecting the cost of capital (e.g., Fama and French 1993\&1997, Francis et al. 2004, Lambert et al. 2007, Garcia Lara et al. 2011, and Li 2015). Belonging to the same stream of research, and particularly focusing on two internal corporate governance mechanisms, this paper investigates the effect of transparency and Board of Directors (BOD) structure on firm's cost of equity capital (COC).

Both transparency and BOD structure are core dimensions of corporate governance. Despite the fact that numerous prior researches (e.g., Chen et al. 2003, Byun et al. 2008, Upadhyay and Sriram 2011, Suchard et al. 2012, and others) have examined the relation between cost of capital and governance measures, results remained inconclusive regarding the extent to which individual monitoring mechanisms affect cost of capital, paving the way for more studies to take place employing different measures and settings. 
Adherence to corporate governance rules is theoretically argued, and empirically supported to reduce firm's cost of capital. Prior studies suggested that weakly governed firms perform poorly during market downturns and thus should be subject to higher COC. Mitton (2002) shows that firms with weak governance performed more poorly during the East Asian financial crisis of 1997-1998. The reasoning is that when insiders are subject to inadequate external monitoring, managers may undertake excessive borrowing, or invest in inefficient projects, thus increasing firm's exposure to market-wide risk, which ultimately increases the cost of capital (Durnev and Kim 2005, and Chen at al. 2009). Moreover, empirical evidence provided by Easley and O'Hara (2004) demonstrates that information asymmetry positively affects a firm's cost of capital. Thus, corporate governance reduces the cost of equity capital by limiting opportunistic managerial practices and mitigating information asymmetry.

Corporate disclosure and transparency are vital for a strong corporate governance framework. Transparency is defined as the extent to which financial reports reveal an entity's underlying economics in a way that is readily understandable by users (Virginia et al 2009). In order to maintain corporate accountability, there is an imperative need for accurate, reliable, timely, and accessible financial and non-financial information. Based on the way prior research (Ball et al. 2000 and Francis et al. 2004) has operationalized transparency, this paper perceives transparency as combined timeliness and conservatism. 


\section{Dr. Mawaheb Abdel-Aziz Ismail}

Timeliness and conservatism are two market-based earnings attributes derived from the view that accounting earnings is intended to measure changes in market value of equity, the so-called economic income. Penman and Zhang (2002) define conservatism as the choice of accounting procedures or estimates that keep the book values of net assets relatively low. Timeliness is an important attribute of earnings quality because timely information is considered an aspect of usefulness to users. Conservatism differs from timeliness in that it reflects the ability of accounting earnings to differentially reflect economic losses (measured as negative stock returns) and economic gains (measured as positive stock returns). Therefore, the reference construct for both timeliness and conservatism is stock returns, but the two constructs differ in that timeliness does not distinguish between positive and negative returns and conservatism focuses on the latter (Watts 2003, Francis et al. 2004, Ball and Shivakumar 2005, and Chen et al. 2007).

The relationship between transparency and cost of capital has motivated many of prior research (Chan et al.2009, Garcia Lara et al. 2011, Li 2015, and Khalifa and Othman 2015), where all reach a negative association between conservatism and COC. The logic underlying such relation was articulated as follows; firm commitment to timely reporting of loss and adherence to full disclosure reduce uncertainty about expected future cash flows, lowering cost of capital (Guay and Verrecchia 2007). Easley and O'Hara (2004) and Lambert et al. (2008) argue that uncertainty leads to the emergence of risk premiums (higher required rate of return) where investors place less weight on imprecise information signals. 


\section{Dr. Mawaheb Abdel-Aziz Ismail}

Regarding BOD structure, corporate governance emphasizes the role of the board as one of its cornerstones. The corporate governance framework (OECD 2004) builds on ensuring BOD's effective monitoring of management. Such effective oversight by the board has the potential of preventing self-dealing and making sure that management looks after shareholders' interests. Company's board is best described as the heart of the company, that is, successful firm must be wellgoverned through an effective well-functioning BOD. Beside the board's traditional role of determining company's goals, setting strategies, and monitoring progress to achieve those goals; BOD has a governance-related role of mitigating agency costs through aligning interests of management and shareholders. According to OECD Principles (2004), the board is chiefly responsible for monitoring managerial performance and achieving an adequate rate of return for shareholders, while preventing conflicts of interests and balancing competing demands on the corporation. Evaluating board performance presents a particular challenge; where board behavior is often unobservable. MENA-OECD report (2010) pointed to the fact that the Egyptian legal framework outlines the specific tasks constituting the boards' responsibilities, but remains silent on its key duties. The issue is left for each company to set some of these details, entailing that actual operation of boards in Egypt is likely to vary among companies. This makes BOD structure a rich area for comprehensive assessment.

A sizeable body of research (such as, Peasnell et al. 2005, Cheng 2008, Suchard et al. 2012, Mazzotta and Veltri 2014, and others) lends support to the effect of board's size, independence, committees, CEO duality on different proxies of firm performance. 


\section{Dr. Mawaheb Abdel-Aziz Ismail}

Board size, constituting an important feature of corporate board, appears to affect investors' perception of a firm's information environment resulting in a greater transparency and a lower cost of capital (Anderson et al. 2004 and Cheng 2008). In addition, it's highly argued that the presence of outside directors tends to reduce the likelihood of financial fraud, where independent directors are more effective in discouraging managers from engaging in earnings management practices (Klein 2006, Lin and Hwang 2010 and Brown et al. 2008). Moreover, existence, independence, activity, and qualification of board audit committee are found to have a significant impact on limiting fraudulent reporting and manipulation of earnings (Truley and Zaman 2004, and Brown et al. 2008). Lastly, CEO duality is proven to impact the functioning of BOD, and in turn firm performance (Reverte 2009).

This paper devotes distinctive focus on Egypt, where I expect that the key features of the Egyptian setting in term of financial markets and corporate governance will impact the relation between corporate governance tools and cost of capital. Egyptian Stock Exchange is characterized by being less developed, highly concentrated, and weakly protected market. The concentrated ownership structure prevailing in the Egyptian Stock Exchange implies that large controlling shareholders have the potential of influencing transparency in management reporting practices in such a way serving their interests. Moreover, those majority shareholders can influence the BOD and committees' agenda.

Building on the above established theoretical and empirical foundations, I predict a negative association between both transparency and BOD structure, and cost of capital. This means that the study hypothesizes that transparency and BOD governance would have a downward impact on firms' cost of equity capital. 


\section{Dr. Mawaheb Abdel-Aziz Ismail}

Moreover, it's expected that BOD governance level may moderate the relationship between transparency and cost of capital. Research hypotheses are examined using a sample of firms listed on the Egyptian Stock Exchange during the period from 2010 to 2017. This period witnessed the adjustment of Egyptian corporate governance code (initially issued in 2005) in 2011, and its further revision in 2016. This motivates the aim of my research, elaborated in investigating the impact of two corporate governance tools, transparency and BOD structure, on COC.

Results reveal that, while transparency has no effect on lowering COC, BOD governance appears to negatively affect COC. Moreover, the interrelation between transparency and BOD structure turns out to be complementary, yet insignificant. This implies the BOD governance has a minor effect on moderating the relation between transparency and COC. However, differential analyses uncover that such interaction effect appears significant at lower levels of transparency (less-transparent firms) and higher levels of BOD governance (wellgoverned BOD firms). Results are shown to be robust to the use of alternative proxies for COC. The paper adds to the literature addressing the effect of different corporate governance mechanisms on COC. The contribution of the study lies in examining more than a single corporate governance tool, which enriches the implications of findings. Prior studies (Klein 2006, Peasnell et al. 2005, and Bowen et al. 2008) focus mainly on board characteristics' impact of earnings management, without considering other aspects as information transparency or ownership structure.

The paper is structured as follows. Section II reviews literature and develops hypotheses. Section III presents sample and research methodology. Empirical results are presented and discussed in section IV. The study concludes with a brief summary in section $\mathrm{V}$.

1 1T

Vol.2, No.1, Part 1., Jan. 2021 


\section{Dr. Mawaheb Abdel-Aziz Ismail}

\section{LITERATURE REVIEW AND HYPOTHESES DEVELOPMENT Transparency and Cost of Capital}

Transparency is a desirable attribute of financial information, supporting credibility in financial markets. Adopting the view of prior research (Ball et al. 2000 and Francis et al. 2004), transparency is perceived as combination of timeliness and conservatism.

The leading study of Basu (1997) highlights the asymmetric timeliness of earnings, where earnings reflect bad news in a timelier fashion than good news. This is caused by the fact that the recognition of economic gains requires stronger verification than recognizing economic losses. Prior literature emphasizes the benefits of conservatism in financial markets. Watts (2003) argues that conditional conservatism acts as a governance tool serving both debt and equity holders. It's maintained that conservatism has a direct effect of minimizing contracting, litigating, regulatory, and taxation costs, thereby increasing firm value. This view is supported by Beekes et al. (2004), Ahmed and Duellman (2007), and Garcia Lara et al. (2009), where all show that better governed firms report more conditionally conservative numbers.

The role of transparency in improving the functioning of capital markets has been analyzed by Guay and Verrecchia (2007), demonstrating that such role lies in the discount the market applies to uncertainty in the absence of information. Intuitively, managers have incentives to disclose only information on good performance and high realizations (Dye 2001). The presence of regulatory enforcement of conservative reporting mitigates such tendency and promotes timely loss recognition. It's well established that full disclosure and transparency reduce cost of capital. Under full disclosure, market participants have timely information on both lower and upper bounds of firm expected cash flows (LaFond and Watts 2008). This reduces information uncertainty and increases the precision with which investors can assess firm future cash flows, minimizing the discount markets apply to firm value.

1 1\%o

Vol.2, No.1, Part 1., Jan. 2021 


\section{Dr. Mawaheb Abdel-Aziz Ismail}

A bulk of empirical studies investigates the relation between transparency and cost of capital, and the results remain inconclusive. On the one hand, supporters of normative accounting theory widely believe that more transparent firms enjoy lower cost of capital. Garcia Lara et al. (2011) document a negative association between conditional conservatism and cost of capital for a large sample of US firms. Using an international setting, Li (2015) reach that firms located in countries with more conservative financial reporting systems have lower cost of capital. That is, the negative association between conditional conservatism and cost of capital is more pronounced in countries with stronger legal enforcement.

Researchers have long debated the concepts of conditional and unconditional conservatism (Beaver and Ryan 2005, Beaver et al. 2005, and Chan et al 2009). Ex ante or unconditional conservatism (news independent) adopts a balance sheet approach, where it reflects the understatement of book values of net assets, unrelatedly to changes in future cash flows. This may include immediate expensing of R\&D and advertising costs, and the accelerated depreciation of tangible assets. Whereas, ex post conservatism, identified by Basu (1997), is market-based, earnings related, and conditional or news dependent. Ex post conservatism is associated with the more timely recognition of economic losses than gains and involves a higher degree of managerial discretion regarding, for example, timing and amount of asset write-down or restructuring charges. Opposing to ex ante conservatism, which tends to more persistent and more predictable by investors, ex post conservatism may be less persistent and less predictable. As to the association with transparency and cost of capital, ex ante conservatism was found to be associated with higher transparency and lower cost of capital, whereas, ex post entails lower transparency and higher cost of capital. 


\section{Dr. Mawaheb Abdel-Aziz Ismail}

On the other hand, the negative association between transparency, cited in conservatism, and cost of capital was discarded by a considerable number of empirical studies (for example, Francis and Schipper 1999, Barth et al. 1998, and Collins et al. 1997). More recently, Givoly and Hayn (2000, 2002) reached that conservatism increases earnings dispersion and declines earnings quality. Also, Easley et al. (2002) and Cheng and Liu (2006) fail to document any association between conservatism and cost of capital. Moreover, Leuz and Wysocki (2008) discard the negative association between transparency and cost of capital.

Motivated by the mixed results concerning the effect of transparency (timeliness and conservatism) on cost of equity capital, and building on the theoretical argument that transparency decreases uncertainty and therefore, lowers cost of capital, the first research hypothesis is formulated as follows:

H1: Firms with higher levels of transparency would show lower levels of cost of equity capital.

\section{Board of Directors Structure and Cost of Capital}

For more than two decades, and since the emergence of corporate governance concept, a massive number of studies (e.g., Dunn 2004, Mishra and Mohanty 2014, Black et al. 2006, Brown et al. 2008, Chen et al. 2009, Klien 1998, Anderson et al. 2004, and others) have been directed towards the investigation of different corporate governance mechanisms on various firm performance indicators. Theoretical foundation establishes a negative relation between corporate governance and cost of capital; where good corporate governance reduces agency problems. The reasoning is that weakly governed firms are exposed to higher risk, inducing investors to raise their required rate of return. Agency theory provides the rationale analysis of the effects of corporate governance on cost of capital, where the separation of ownership and control creates problems of information asymmetry between shareholders and managers, leading to an agency risk (Shleifer and Vishny 1997). Higher premium required by rational investors to bear agency risk raises cost of capital.

ITV

Vol.2, No.1, Part 1., Jan. 2021 


\section{Dr. Mawaheb Abdel-Aziz Ismail}

Not only agency theory that supports the importance of corporate governance, but also transaction cots theory promotes BOD governance. Transaction costs theory, as expressed by Solomon (2007), demonstrates that as firms have grown in size, more capital is required to be raised from capital market through wider ownership base. In other words, the more firm becomes larger, the more transactions it undertakes and will expand up to the point where it becomes cheaper or more efficient for management to externalize transactions. Strong corporate governance rules and effective BOD structure have the potential of reducing the costs of any misaligned actions taken by mangers through structuring the type, timing, terms of transactions to serve their own benefits. Nordberg (2010) argues that transaction costs theory is built on two assumptions; bound rationality and opportunism. Both assumptions believe that managers organize transactions in their best interest, and this practice needs to be controlled through effective supervisory role played by BOD.

BOD composition is one of the main dimensions of corporate governance which attracted the attention of corporate governance researchers. A large body of research (Mazzotta and Veltri 2014, Suchard et al. 2012, Upadhyay and Sriram 2011, Elsayed 2007 \& 2011, and others) investigates the features shaping BOD structure to trace its effect on firms' performance measures. Size, independence, audit committee, and CEO duality are the main features constituting BOD structure.

Board size is one important characteristic of corporate boards that directly affects its governance. Two lines of thoughts are provided by literature, the first promotes a small board size, while the other supports a large board size, and each has its critical reasoning. Proponents of a small-sized board argues that members in small boards have more effective communication, higher degree of coordination, greater speed in solving problems, lower incidence of free-rider problems, and higher degree in meetings participation ( $\mathrm{Wu} 2000)$. This view is consistent with prior researchers, Lipton and Lorsch (1992), and Jensen (1993), who argue that independent directors in large boards are less likely to function effectively where it becomes more difficult for them to express their views and opinions. Moreover,

IT人

Vol.2, No.1, Part 1., Jan. 2021 


\section{Dr. Mawaheb Abdel-Aziz Ismail}

CEO may face problems in controlling large boards, which could aggravate agency problems between CEO and investors, leading to less transparent information environment and greater opportunity for managers to seek their own interests. Accordingly, investors may require a higher rate of return in case of large boards (Yermack 1996).

Advocates of large-sized boards claim that a larger board has greater resources to monitor managerial performance. By forming various monitoring committees, and by allocating specific tasks, larger board facilitates greater discussion on corporate issues, leading to more transparency (Klein 2006, Anderson et al. 2004, and Upadhyay and Sriram 2011). Additionally, shareholders are found to view financial information reported by large boards as more reliable, and are willing to lower their required rate of return (Anderson et al. 2004).

For Egyptian context, Companies are organized under a one-tier board system. Boards appear to be relatively large, with an average of nine members, possibly to be legal entities. Supporting a valid negative relationship between board size and governance of BOD, I believe that above an upper limit, each additional member would most likely add more inefficiency that may not be compensated by increase in competency and diversity of the directors. Therefore, the paper expects a decrease in BOD governance when board size increases above certain limit.

Independence is another distinctive attribute of BOD. Prior research (Fama and Jensen 1983, Park and Shinn 2004, and Patelli and Prencipe 2007) establishes that independent non-executive directors can monitor and control the opportunistic actions of executives, mitigating agency problems between managers and shareholders, and between majority and minority shareholders. A massive number of studies support the positive impact of outside directors in constraining fraudulent financial reporting practices and decreasing the likelihood of firms' financial distress and bankruptcy (Anderson and Reeb 2004, Dunn 2004, Daily et al. 2003, and others).

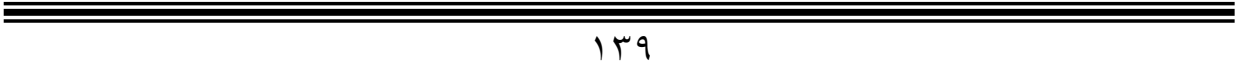

Vol.2, No.1, Part 1., Jan. 2021 


\section{Dr. Mawaheb Abdel-Aziz Ismail}

Considering Egyptian setting, until 2016, there was no legal requirement for boards to have independent members, but the listing rules of the Egyptian Stock Exchange now require that all listed companies have at least two independent directors. The study expects that more independent BOD would increase board governance.

Regarding board committees, corporate governance literature suggests the presence of internal committees, to which the BOD can delegate functions and tasks, can increase BOD governance and corporate governance quality. Board internal committees are audit committee, remuneration committee, nomination committee, and risk management committee. Literature devoted much analysis for the impact of audit committee because of its vital role. The main task of audit committee is to set the guidelines of internal control system, verify its validity, adequacy and functioning, and strengthening financial reporting process and facilitating the detection and prevention of corporate misconduct. Empirical studies provide evidence promoting the significant impact of strong audit committees on limiting irregularities, misstatements and other indicators of unreliable financial reporting (Truley and Zaman 2004, Brown et al. 2008, and Mendez and Garcia 2007). It's highly demonstrated that not only the presence of audit committee that matters, but also its independence, activity, and qualification.

In Egypt, the only committee that listed companies are required to have is the audit committee. In 2016, listing rules of the Egyptian Stock Exchange specified a requirement that audit committees be comprised of at least three non-executive board directors, two of whom are independent. I expect that the existence of an independent, active, and qualified audit committee would increase the governance of BOD.

The separation between CEO and board's chairman is perceived to be an important feature of BOD governance. Theoretically, it is assumed that the eventuality that a single person shares the responsibilities of both chairman and CEO can increase the risk that controlling managers on the board is somehow limited or distorted. Some studies (e.g., Dalton et al. 1998, and Elsayed 2007) find no significant relationship between the dual roles and performance. While others (e.g., Wahba 2015) reach that CEO duality negatively affect firm financial performance.

$$
1 \leqslant .
$$

Vol.2, No.1, Part 1., Jan. 2021 


\section{Dr. Mawaheb Abdel-Aziz Ismail}

In Egypt, the law does not require the roles of the board's chairman and CEO to be split and it seems that combining these roles is a common practice. However, the paper expects that such duality adversely affects BOD governance.

Building on the above analysis, the second research hypothesis can be formulated as follows:

H2: Firms with well-governed BOD would show lower levels of cost of equity capital.

Corporate governance literature documents that various governance mechanisms may interact with one another to reshape their relation with firm performance measures (e.g., Brunninge et al. 2007, Florackis 2008, Sulong and Nor 2010, Upadhyay and Sriram 2011, Khanqah 2015, and others).

Transparency and BOD structure may exhibit a complementary relationship if the impact of BOD governance is conditional on level of transparency. That is, the two mechanisms support each other resulting in further reduction in COC. On default basis, such complementary relationship is assumed; where the OECD Principles (2004) suggest that board members should act on a fully informed basis in the best interest of the company and its shareholders. In determining boards' exact responsibilities, the Principles specify that BOD must ensure the integrity of company's accounting and financial reporting systems, and oversee the process of disclosure and communication. Therefore, the two corporate governance rules, transparency and BOD governance, are closely bounded to each other; an effective BOD has an important role of assuring the transparency of information provided by managers to shareholders.

Additionally, a substitute relationship between transparency and BOD governance may arise. This would happen if the effect of BOD governance is offset by transparency; that is investors in highly transparent firms do not benefit from supervisory role taken by BOD (Upadhyay and Sriram 2011). Therefore, the third research hypothesis can be formulated as follows:

H3: BOD structure would moderate the relationship between transparency and firms' cost of capital. 


\section{RESEARCH DESIGN}

\section{Data and Sample Selection}

Initial study sample comprises 118 most active firms continuously listed on the Egyptian Stock Market during the period 2010-2017. Study period seems critical, where the Egyptian Code of Corporate Governance (initially introduced in October 2005) was firstly revised in 2011, and recently adjusted in August 2016. Therefore, this helps tracing the effect of adjustments, if any, on firms operating in the Egyptian Stock Exchange. Moreover, this period evidenced major economic and political events in the Egyptian setting, so it's convenient to find out the effect of such changes, if any, on different aspects of firms. Firms' financial data were obtained through annual reports available on the website of "Mubasher Misr". Nonfinancial data concerning BOD characteristics were manually extracted from supplementary notes related to financial statements.

To ensure homogeneity of data, companies belonging to financial sector were excluded since they operate in different regulatory environments than those of other companies. Also, companies with missing data of study variables were excluded. Since the measurement of the study's dependent variable (cost of capital) imposes certain limitations (as will be discussed), I exclude firms showing negative differences in earnings per share, also firms with no dividends payment. As a consequence, final sample comprises 74 firms belonging to five sectors.

Data Sample selection and distribution are presented in Table (1). 
Table (1)

Sample Selection and Distribution

\begin{tabular}{|c|c|c|c|}
\hline \multicolumn{4}{|c|}{ Panel A: Sample Selection } \\
\hline \multicolumn{3}{|l|}{ Initial Sample } & 118 \\
\hline \multicolumn{3}{|l|}{ Excluding: } & \\
\hline \multicolumn{3}{|c|}{ Banks and Financial Service companies } & (14) \\
\hline \multicolumn{3}{|c|}{ Companies with missing data of study variables } & (4) \\
\hline \multicolumn{3}{|c|}{ Companies showing negative EPS differences } & $(15)$ \\
\hline \multicolumn{3}{|c|}{ Companies declaring no dividends } & $(11)$ \\
\hline \multicolumn{3}{|l|}{ Final Sample } & 74 \\
\hline \multicolumn{4}{|c|}{ Panel B: Sample Distribution by Industry } \\
\hline Industry & Firms & Observations & $\%$ \\
\hline $\begin{array}{c}\text { Construction \& } \\
\text { Materials } \\
\end{array}$ & 25 & 200 & 34 \\
\hline $\begin{array}{c}\text { Chemicals \& } \\
\text { Pharmaceuticals }\end{array}$ & 10 & 80 & 14 \\
\hline $\begin{array}{c}\text { Industrial \& Basic } \\
\text { Resources }\end{array}$ & 19 & 152 & 26 \\
\hline $\begin{array}{c}\text { Leisure \& } \\
\text { Entertainment }\end{array}$ & 13 & 104 & 17 \\
\hline $\begin{array}{c}\text { Media \& } \\
\text { Communications }\end{array}$ & 7 & 56 & 9 \\
\hline Total & 74 & 592 & 100 \\
\hline
\end{tabular}

Vol.2, No.1, Part 1., Jan. 2021 


\section{Measurement of Research Variables:}

\section{Dependent variable: Cost of Capital}

In fact, the estimation of COC has been perceived as one of the most disputed themes in finance literature (Brealey et al. 2007). The reason is that COC is not directly observable, and its estimation relies on other estimated data; expected returns.

Recent accounting and finance literature provide four models to estimate COC. These models are either based on residual income valuation model, Claus and Thomas (2001), and Gebhardt et al. (2001), or abnormal earnings growth valuation model, Easton (2004), and Ohlson and Juettner-Nauroth (2005). All models employ almost the same main variables with different specifications; mean earnings forecast, market stock price, book value per share, and dividend payout.

It's worth mentioning that literature provides little guidance on the relative performance of a model over another, and some studies (Hail and Leuz 2006, and Dhaliwal et al. 2006) estimate COC as the average of the four models in order to avoid measurement errors associated with a certain model. Moreover, it's out of my research scope to illustrate and discuss COC models' specifications and reliability.

Following prior studies adopting ex ante methods for estimating COC, I employ PEG (Price-Earnings Growth) model, developed by Easton (2004), in calculating COC. PEG model has been evaluated reliable by Botosan and Plumlee (2005), and Easton and Monahan (2005). They show that PEG model clearly dominates all other alternatives in terms of empirical relationship with the risk proxies and adjusted $\mathrm{R}^{2}$ of the regression. Moreover, PEG model has proven its suitability and usefulness in estimating COC for European countries (Chen et al. 2004), and in cross-country studies (Lee et al. 2006, and Mangena et al. 2010). A last justification for using PEG model is that; a considerable number of studies (e.g., $1 \leqslant \varepsilon$

Vol.2, No.1, Part 1., Jan. 2021 


\section{Dr. Mawaheb Abdel-Aziz Ismail}

Byun et al. 2008, Reverte 2009, Mazzotta and Veltri 2014) examining the relationship between $\mathrm{COC}$ and different corporate governance mechanisms have used PEG model, which facilitates comparison of results.

COC of firm (i) for year ( $\mathrm{t}$ ) is estimated using the following formula:

$$
\mathrm{COC}_{i t}=\sqrt{ }\left[\left(\mathrm{EPS}_{\mathrm{it}+2}-\mathbf{E P S}_{\mathrm{it}+1}\right) / \mathbf{P}_{\mathrm{it}}\right] \text {---------------(1) }
$$

Where,

$\mathrm{EPS}_{\mathrm{it}+2}$ and $\mathrm{EPSit}_{+1}$ represent earnings per share for firm (i) for two-years and oneyear ahead respectively.

$\mathrm{P}_{\text {it }}$ is the stock market price for firm (i) at the end of the fiscal year.

It should be mentioned that PEG model utilizes analysts' forecasts for EPS, however, it is common in the finance and accounting literature to use realized or actual figures to proxy for expected ones if the latter is missing or difficult to estimate. Since the Egyptian Stock Exchange lacks to analysts' forecasts, then I employ realized EPS. Moreover, COC cannot be computed when $\mathrm{EPS}_{\mathrm{it}+2}<\mathrm{EPS}_{\mathrm{it}+1}$, so this was considered in the sample selection, where firms recording negative differences were eliminated. It's noteworthy that same handling was previously performed by Byun et al. (2008), and Mazzotta and Veltri (2014).

Additionally, the sensitivity analysis will measure COC based on dividends growth rate. 


\section{Independent Variables}

\section{(1) Transparency}

Following the interpretation of prior studies (Ball et al. 2000, Bushman et al. 2002, and Francis et al. 2004) viewing transparency as combined timeliness and conservatism. Both measures are based on reverse regression of earnings on returns; where timeliness is the explanatory power of the regression, and conservatism is the ratio of slope coefficients on negative returns to slope coefficients on positive returns.

Timeliness and conservatism are computed using the following regression (Basu 1997) using earnings as dependent variable and returns as independent variable:

Earnit $_{i t}=\lambda_{0}+\lambda_{1}$ DumRetit $+\lambda_{2}$ Retit $_{i}+\lambda_{3}$ DumRet $_{i t} *$ Ret $_{i t}+\dot{\varepsilon}_{\mathrm{it}}-------(2)$

Where;

Earn $_{i t}$ is the earnings before extraordinary items of firm (i) in year ( $t$ ) scaled by market value of equity.

DumRet $_{i t}$ is a dummy variable equals 1 if Ret $_{i t}<0$ (negative returns), and zero otherwise.

Ret ${ }_{i t}$ firm (i)'s return measured as $\left(\mathrm{P}_{\mathrm{t}+1}-\mathrm{P}_{\mathrm{t}}\right) / \mathrm{P}_{\mathrm{t}}$. Realized stock return is used which, as argued by Daouk et al. (2006), is free from estimation errors.

Timeliness is the negative of explanatory power of the above regression (Ball et al.

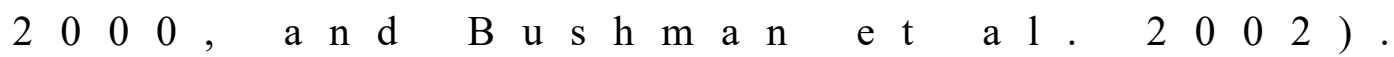
Timeliness $=-\mathbf{R}^{2}$

Conservatism is the negative of the ratio of the coefficient on bad news to the coefficient of good news (Basu 1997, Pope and Walker1999, and Givoly and Hayn 2000): 


\section{Dr. Mawaheb Abdel-Aziz Ismail}

$$
\text { Conservatism }=-\left[\left(\lambda_{2}+\lambda_{3}\right) / \lambda_{3}\right]
$$

Larger values of timeliness and conservatism imply less timely earnings and less conservative earnings, respectively, than do smaller values (Francis et al. 2004). Confirmatory factor analysis is used to combine timeliness and conservatism into one factor "Transparency", or T-Score.

Table (2) illustrates the specifications of confirmatory factor analysis:

Table (2)

Outputs of Confirmatory Factor Analysis of Transparency proxies

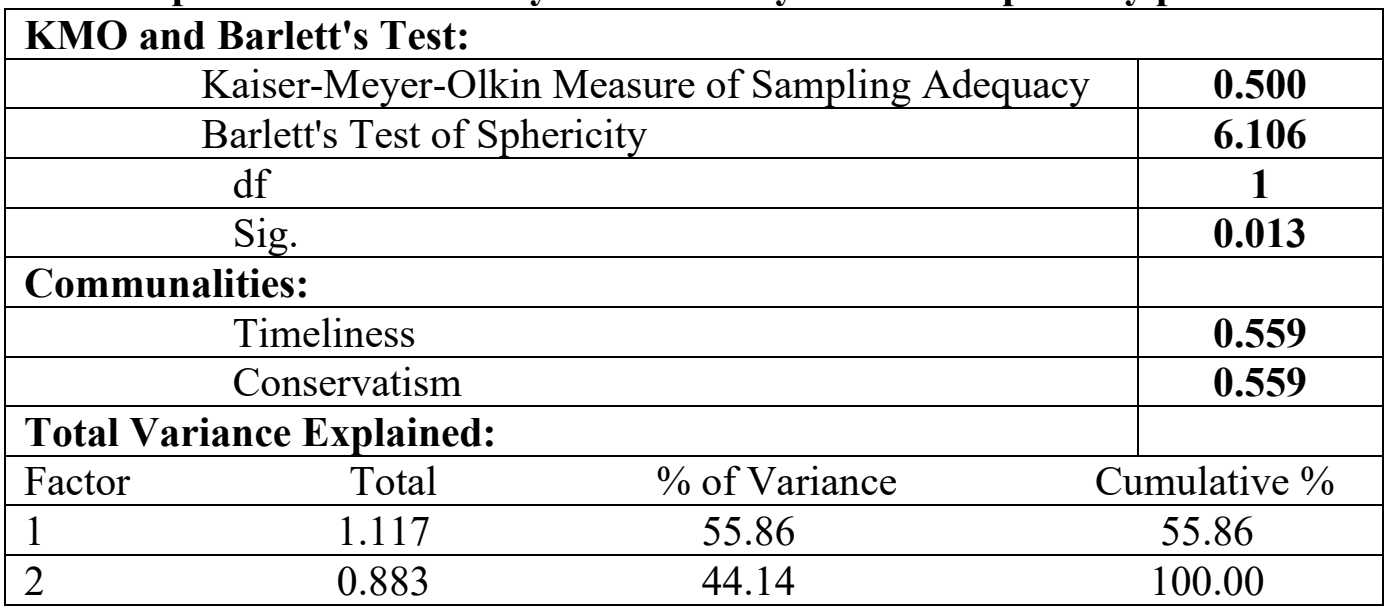

(2) BOD Structure

I construct a BOD-Score measure identifying the four chosen attributes defining BOD governance; board size, board independence, board audit committee, and CEO duality (Byun et al. 2008, Reverte 2009, and Mazzotta and Verltri 2014).

\section{1- Size:}

I determine the board size for each sample firm, and in order to capture the differing governance implications of board size, a dummy variable is created, equals 1 if board size is less than the sample median and 0 otherwise. This is based on the documented negative relationship between board size and governance of 


\section{Dr. Mawaheb Abdel-Aziz Ismail}

BOD, where above the upper limit (median), each additional member adds inefficiency (Mazzotta and Veltri 2014, and Upadhyay and Sriram 2011).

\section{2- Independence:}

Based on the analysis provided in the previous section, the study hypothesizes a positive relationship between board independence and BOD governance. The Egyptian corporate governance code recommends that boards should be comprised of a majority of independent non-executive members. In order to assess the impact of board independence on governance, a dummy variable is created, equals 1 if the board contains at least 50\% independent non-executive members, and 0 otherwise.

It's worth emphasizing that independence implies that there are no relationships or circumstances that might affect directors' judgment, where independent nonexecutive should be independent of management and free from any business or other relationship which materially interfere with exercising their independent judgment. That is, they should not be closely related to the company or its management through significant economic, family or other ties. Literature (Brickley et al. 1994, Bazcuk 2011, and others) suggests many situations that might hit independence; for example, being a former employee in the company within the last five years, having a material business relationship with the company in the last 3 years, being served on the board for more than ten years, or being a significant shareholder in the company.

\section{3- Audit Committee:}

Audit committees are often perceived as an effective mechanism reducing agency cost and are expected to monitor the reliability of the company's accounting processes and compliance with relevant corporate legal and ethical standards (Turley and Zaman 2004). It's well established that the mere formation of audit committee in organization results in substantial benefits, cited in enhancing third

\section{$1 \leqslant \wedge$}

Vol.2, No.1, Part 1., Jan. 2021 


\section{Dr. Mawaheb Abdel-Aziz Ismail}

party perception of auditor independence, increasing audit quality, and limiting managerial opportunistic behavior (Mendez and Garcia 2007, and Brown et al. 2008). However, world-wide corporate scandals uncover that it's not all of these perceived potentials were achieved by adoption of audit committee concept. Further, in some cases audit committee aides the failure of some corporations either intentionally or passively (Dodo 2017). Therefore, in order to perform effectively, audit committee should not be only existing, but also qualified, independent, and active.

Based on the postulated positive link between the existence, composition, and activity of an audit committee and BOD governance, a dummy variable is created, equals 1 if: (1) an audit committee exists, (2) comprised of at least three independent members, and (3) meets at least four times annually, and 0 otherwise (Brown et al. 2008, and Mendez and Garcia 2007).

\section{4- CEO Duality:}

Building on the assumed negative effect of duality on board governance, a dummy variable is created, equals 1 if the roles of CEO and board chairman are split, and 0 otherwise (Elsayed 2007, and Wahba 2015).

My BOD governance index, "BOD-Score", is a summary measure formed by summing up the above dummies. The same weight is assigned to each variable because of their equal significance in defining BOD governance. Thus, BOD-Score would take the values from 0 (poorly governed BOD) to 4 (well governed BOD).

The approach of obtaining a comprehensive score was adopted by prior studies, such as Byun et al. (2008), Ausbaugh-Skaife et al. (2004), and Mazzotta and Veltri (2014). Employing an overall score seems advantageous compared with the use of single attribute measure, since it solves the correlated omitted variable problems, where each of the four variables correlated predicts COC on a separate basis.

$1 \leqslant 9$

Vol.2, No.1, Part 1., Jan. 2021 


\section{Dr. Mawaheb Abdel-Aziz Ismail}

\section{Control Variables}

To investigate the effect of transparency and BOD structure on cost of equity capital, some control variables are introduced into the multivariate analyses in order to account for firms' specific characteristics, mainly risk levels. Following prior studies (Francis et al. 2004, Upadhyay and Sriram 2011, Mazzotta and Veltri 2014, and Shahwan 2015), the variables below are included in the regression:

1- Size; where larger firms tend to show lower risk levels, and are more likely to adhere to transparency regulations and BOD governance. Size is measured as the natural logarithm of firm's total assets (Suchard et al. 2012, Shahwan 2015, and Li 2015). Firm size is expected to be negatively related to $\mathrm{COC}$.

2- Market-to-book ratio; used to indicate firm's market risk perception, where firms with higher MTB tend to show lower risk levels, and most probable to be well-governed firms. MTB is measured by the ratio of market value to the book value of common equity (Garcia Lara et al. 2011, Mazzotta and Veltri 2014, and Shahwan 2015). MTB is expected to be negatively related to COC.

3- Leverage; a risk measure indicator; where high leveraged firms tend to be more risky because of using more discretionary accruals to avoid covenant violation. Leverage is measured as firm's total liability deflated by book value of equity (Upadhyay and Sriram 2011, Mazzotta and Veltri 2014, and Shahwan 2015). Leverage is expected to be positively associated with COC.

4- Debt to assets ratio; another risk measure assessed as total liabilities deflated by total assets. Firms with high debt ratio tend to show higher risk levels, are more likely to face financial distress and bankruptcy (Shahwan 2015 and Mazzotta and Veltri 2014). As all risk measures, it is expected that debt to assets ratio to be positively associated with COC.

10.

Vol.2, No.1, Part 1., Jan. 2021 


\section{Dr. Mawaheb Abdel-Aziz Ismail}

\section{Regression Models}

As discussed in the literature review section, transparency lends firms credence and reliability through decreasing information asymmetry and uncertainty. Researchers document the benefits of transparency to potential investors who in turn lower their required rate of return on their investments. Financial reporting quality has been proven to be equally important to both equity and bond holders (Easley and O'Hara 2004, and Gietzmann and Ireland 2005). Nevertheless, such negative association between transparency and COC has been denied by other empirical studies (Leuz and Wysocki 2008, Easley et al. 2002 and Cheng and Liu 2006).

Building on the well-established agency theory, this paper firstly hypothesizes a negative relationship between transparency and firms' cost of capital.

The second research hypothesis predicts that BOD governance is negatively related to COC. This prediction is based on the fact that BOD is the dynamo of the firm, which assumes to direct and control each and every aspect of the company. A well-governed BOD is more likely to apply and follow corporate governance guidelines, promoting higher levels of performance.

Specifically, the following model is employed to test both first and second hypotheses:

$\mathrm{COC}_{i t}=\beta_{0}+\beta_{1}$ T-Score $i t+\beta_{2}$ BOD-Score $_{i t}+\beta_{3-6}$ Controlsit $_{\text {it }}+\grave{\varepsilon}_{i t}--------(3)$

Where;

$\mathrm{COC}_{\mathrm{it}}$ is the firm's cost of equity capital computed using equation (1).

T-Score $i$ is the firm's transparency factor obtained from confirmatory analysis of timeliness and conservatism.

101

Vol.2, No.1, Part 1., Jan. 2021 


\section{Dr. Mawaheb Abdel-Aziz Ismail}

BOD-Score is the firm's BOD governance index obtained from summing up dummy variables defining BOD structure, namely size, independence, audit committee, and duality.

Control variables are as previously discussed; namely size, MTB, leverage, and debt ratio.

Theoretical foundation and empirical evidence (Klein 2006, Bowen et al. 2008, and Cheng 2008) suggest that BOD structure does impact financial reporting quality, where it is unexpected to achieve transparency under a poorly-governed BOD. Moreover, BOD structure is unexpected to influence COC in an opaque firm environment. This entails that an interaction between transparency and BOD structure is assumed to exist. Thus, my third hypothesis postulates that BOD structure moderates the relationship between transparency and firms' cost of capital.

Equation (3) is extended to include the interaction term of the two independent variables. This is illustrated by the following linear-multiple regression analysis:

COC $_{i t}=\beta_{0}+\beta_{1}$ T-Score $_{i t}+\beta_{2}$ BOD-Score $_{i t}+\beta_{3}$ T-Score $_{i t} *$ BOD-Score $_{i t}$ $+\beta_{4-6}$ Controls ${ }_{i t}+\dot{\varepsilon}_{\text {it }}-----------(4)$

For the interaction term, it's expected that its coefficient $\left(\beta_{3}\right)$ to be negative if the relation between transparency and BOD governance turns out to be complementary, whereas the coefficient is expected to be positive if the two variables turn to be substitutes. 


\section{Dr. Mawaheb Abdel-Aziz Ismail}

\section{Empirical Results}

Table (3) presents descriptive statistics for study main and control variables.

Table (3)

\section{Descriptive Statistics of Study Variables}

( $\mathrm{N}=592$ observations)

\begin{tabular}{|c|c|c|c|c|c|c|c|c|c|}
\hline Variable & Mean & Std. Dev. & Min & Q1 & Median & Q3 & Max & Kurtosis & Skewness \\
\hline COC & $\mathbf{0 . 4 4 1 4}$ & $\mathbf{0 . 6 4 7 2}$ & $\mathbf{0 . 0 0 9 4}$ & $\mathbf{0 . 1 5 7 3}$ & $\mathbf{0 . 2 5 6 3}$ & $\mathbf{0 . 4 4 6 2}$ & $\mathbf{6 . 9 8 9 5}$ & $\mathbf{5 . 6 5 9}$ & $\mathbf{2 . 4 7 3}$ \\
\hline T-Score & $\mathbf{- 0 . 0 0 2}$ & $\mathbf{1 . 0 0 0 4}$ & $-\mathbf{4 . 7 3 7 8}$ & $\mathbf{- 0 . 4 8 9}$ & $\mathbf{- 0 . 0 1 2 0 2}$ & $\mathbf{0 . 5 3 1 9}$ & $\mathbf{1 . 8 9 0 7}$ & $\mathbf{- 1 . 0 7}$ & $\mathbf{- 1 . 3 7 8}$ \\
\hline BODScore & $\mathbf{2 . 2 5}$ & $\mathbf{0 . 9 3 9}$ & $\mathbf{0}$ & $\mathbf{2}$ & $\mathbf{2}$ & $\mathbf{3}$ & $\mathbf{4}$ & $\mathbf{- 0 . 5 0 2}$ & $\mathbf{0 . 1 7 7}$ \\
\hline Size & $\mathbf{1 9 . 9 0 2}$ & $\mathbf{1 . 6 0 9 5}$ & $\mathbf{1 6 . 2 4 4 8}$ & $\mathbf{1 8 . 6 7 7}$ & $\mathbf{1 9 . 7 7 9}$ & $\mathbf{2 0 . 9 4 9}$ & $\mathbf{2 4 . 3 3 4}$ & $\mathbf{- 0 . 3 0 8}$ & $\mathbf{0 . 4 7 0}$ \\
\hline MTB & $\mathbf{1 . 9 8 8 2}$ & $\mathbf{2 . 4 4 8 6}$ & $\mathbf{0 . 0 0 4 6}$ & $\mathbf{0 . 6 2 4 5}$ & $\mathbf{1 . 2 3 8 0}$ & $\mathbf{2 . 2 1 9 0}$ & $\mathbf{2 4 . 8 1 0}$ & $\mathbf{2 . 1 5 7}$ & $\mathbf{2 . 1 1 6}$ \\
\hline Lev & $\mathbf{2 . 2 4 9 1}$ & $\mathbf{3 . 3 3 9 7}$ & $\mathbf{0 . 0 0 0 5}$ & $\mathbf{0 . 2 9 3 3}$ & $\mathbf{0 . 9 2 7 8}$ & $\mathbf{2 . 3 8 4 4}$ & $\mathbf{2 4 . 6 9 4}$ & $\mathbf{8 . 3 5 6}$ & $\mathbf{2 . 6 2 5}$ \\
\hline D/A & $\mathbf{0 . 4 1 5 9}$ & $\mathbf{0 . 4 7 5 6}$ & $\mathbf{0 . 0 0 0 5}$ & $\mathbf{0 . 1 3 6 5}$ & $\mathbf{0 . 3 5 6 2}$ & $\mathbf{0 . 5 6 4 9}$ & $\mathbf{0 . 7 3 4 2}$ & $\mathbf{7 . 6 5 0 6}$ & $\mathbf{2 . 6 7 3 3}$ \\
\hline
\end{tabular}

Table (3) shows that study's dependent variable, COC, has an average and median of 0.44 and 0.25 respectively, distributed normally (5.65). T-Score appears to be negatively skewed with negative mean and median $(-0.002,-0.012)$. This is not unexpected, where components of T-Score, timeliness and conservatism, are computed based on negative explanatory power of regressing earnings on returns, and the negative of the ratio of the coefficient on bad news to the coefficient of good news. The only dichotomous variable, BOD-Score, is normally distributed with a mean of 2.25 and a median of 2. Since it's composed of four dummy variables, it shows a minimum of zero and a maximum of 4 . Main variables show low differences between their means and medians, as well as low standard deviation, denoting minor dispersion for these metrics. Regarding control variables, all show low dispersion cited in low standard deviations and ranges. Skewness and kurtosis values ensure the normality of variables, with a threshold of \pm 3 for skewness as recommended by Hair et al. (2006), and threshold of \pm 10 for kurtosis, as suggested by Kline (1998).

104

Vol.2, No.1, Part 1., Jan. 2021 
Table (4)

Correlation Matrix of Study Variables

\begin{tabular}{|c|c|c|c|c|c|c|c|}
\hline Variables & COC & T-Score & $\begin{array}{l}\text { BODScor } \\
\text { e }\end{array}$ & Size & MTB & Lev & D/A \\
\hline COC & 1 & & & & & & \\
\hline T-Score & 0.02 & 1 & & & & & \\
\hline $\begin{array}{l}\text { BODScor } \\
\text { e }\end{array}$ & $-0.037^{*}$ & $-0.063^{*}$ & 1 & & & & \\
\hline Size & 0.050 & $0.192^{* *}$ & $-0.233^{* *}$ & 1 & & & \\
\hline MTB & $-0.153^{* *}$ & -0.032 & $-0.285^{* *}$ & 0.047 & 1 & & \\
\hline Lev & $0.201 * *$ & -0.006 & $-0.199 * *$ & $0.332^{* *}$ & $0.228^{* *}$ & 1 & \\
\hline D/A & $0.119 *$ & 0.031 & 0.064 & -0.060 & -0.027 & $0.423 * *$ & 1 \\
\hline
\end{tabular}

**Correlation is significant at the 0.01 level (2-tailed).

*Correlation is significant at the 0.05 level (2-tailed).

Table (4) illustrates Pearson correlation coefficients among study variables. COC appears to be positively and insignificantly associated with T-Score. BODScore turns out to be negatively and significantly associated with $\mathrm{COC}$, implying that firms with well-governed BOD enjoy lower COC. Larger firms did not enjoy lower COC as expected, where size appears to be positively correlated with COC. Firms with high market-to-book values enjoy lower COC, indicated by the negative significant correlation coefficient. Risk measures, leverage and debt to asset ratio, show positive significant association with COC, revealing that risky firms bear higher COC. The two independent variables are negatively correlated, predicting that an interaction effect may exist. BOD-Score shows negative significant correlation with size, MTB, and leverage, implying the impact of BOD structure on firms' specific variables. Values confirm the absence of multi-collinearity, where no coefficient exceeds 0.8 (Hair et al. 2006). Moreover, variance inflation factors (VIFs) for variables were examined to ensure low values (less than 10) so that the effect of multi-collinearity is avoided.

$10 \xi$

Vol.2, No.1, Part 1., Jan. 2021 


\section{Fundamental Analysis:}

Since the paper is interested in investigating both separate and joint effects of transparency and BOD structure on COC, two models are employed. Model 1 will test the first two hypotheses; by examining the separate effect of independent variables on COC (equation 3). Model 2 will test the third hypothesis; by investigating the interaction effect of independent variables on COC (equation 4). Table (5) presents the outputs of the two models:

Table (5)

Results of Regression Analysis for the effect of Transparency and BOD Structure on COC

\begin{tabular}{|c|c|c|c|c|c|c|}
\hline \multicolumn{3}{|c|}{ Model (1) } & \multicolumn{4}{|c|}{ Model (2) } \\
\hline Variable & $\boldsymbol{\beta}$ & $t$ & Sig. & $\beta$ & $\mathbf{t}$ & Sig. \\
\hline Constant & 0.837 & 1.895 & 0.059 & 0.837 & 1.884 & 0.060 \\
\hline T-Score & 0.070 & 0.152 & 0.0879 & 0.080 & 0.060 & 0.090 \\
\hline BODScore & -0.062 & -1.247 & 0.0213 & -0.062 & -1.245 & 0.0214 \\
\hline TScore*BODScore & & & & -0.001 & -0.009 & 0.0993 \\
\hline Size & -0.037 & -0.707 & 0.480 & -0.037 & -0.701 & 0.484 \\
\hline MTB & -0.226 & -4.597 & 0.000 & -0.226 & -4.589 & 0.000 \\
\hline Lev & 0.248 & 4.311 & 0.000 & 0.248 & 4.304 & 0.000 \\
\hline D/A & 0.009 & 0.176 & 0.086 & 0.009 & 0.176 & 0.086 \\
\hline $\mathbf{N}$ & & 592 & & & 592 & \\
\hline R-Sq & & 0.086 & & & 0.089 & \\
\hline $\mathbf{F}$ & & 6.857 & & & 5.864 & \\
\hline P-value & & 0.000 & & & 0.000 & \\
\hline
\end{tabular}

Table (5) presents results of regressing cost of equity capital on transparency and BOD structure. Results indicate the significance of the two models (zero Pvalue). In model (1), T-Score reports a positive insignificant coefficient $(0.07$, 0.08), implying a negligible impact of transparency on COC. Put it another way, transparency have no effect on lowering COC. This drives the Rejection of the first hypothesis predicting a negative relationship between transparency and COC. 


\section{Dr. Mawaheb Abdel-Aziz Ismail}

This result supports evidence provided by previous studies, for example, Givoly and Hayn (2000, 2002), Easley et al. (2002), Cheng and Liu (2006), and Leuz and Wysocki (2008). All these studies discard the negative association between transparency and cost of capital. Nevertheless, my results contradict evidence provided by Garcia Lara et al. (2011), and Li (2015) which supports the positive impact of transparency on lowering COC.

Also, model (1) shows that BOD-Score has a negative significant coefficient $(-0.062,0.02)$, revealing a significant effect of BOD governance on lowering COC. This implies the Acceptance of the second hypothesis predicting a negative relationship between BOD structure and COC. This result agrees with those of Mazzotta and Veltri (2014), Suchard et al. (2012), and Upadhyay and Sriram (2011); where all suggest that well-governed BOD has the effect of lowering COC.

In Model (2), the interaction term turns out to be negative and insignificant $(-0.001,0.09)$. This points to a complementary relationship between transparency and BOD structure, yet insignificant. This implies the Rejection of third hypothesis predicting a joint impact of transparency and BOD structure. Therefore, BOD structure is not promoted to moderate the relationship between transparency and firms' cost of capital. This result contradicts evidence provided by Upadhyay and Sriram (2011); which reach that transparency has a moderating impact on the relationship between board size and COC. Specifically, they document that the impact of board size on COC is conditional on the level of transparency; which is not the case here.

Regarding control variables, coefficients and significance did not show any difference under the two models. Only MTB and leverage show significant coefficients, indicating their considerable impact on $\mathrm{COC}$ for the sample firms. Coefficients of control variables verify expectations, where size and MTB are negatively related to $\mathrm{COC}$, while leverage and $\mathrm{D} / \mathrm{A}$ show positive coefficients. 


\section{Dr. Mawaheb Abdel-Aziz Ismail}

\section{Additional Analysis:}

In order to check the robustness of my results, an additional analysis is performed involving splitting sample firms according to:

(1) Transparency levels, and

(2) BOD governance levels;

where the aim is to trace the impact of differential levels of independent variables on COC.

\section{1- Differential Impact of Transparency Levels on COC:}

Around the median of T-Score (-0.012), firm-year observations are split into: -More Transparent firms; whose T-Score is less than or equal the median, and -Less Transparent firms; whose T-Score is greater than the median.

This approach has been adopted by previous studies, such as Upadhyay and Sriram (2011), and others.

The following two tables illustrate the regression outcomes for the two sub-groups under the two models. 
1) More Transparent Firms:

Table (6)

Results of Regression Analysis for the effect of Transparency and BOD Structure on COC For More Transparent Firms

\begin{tabular}{|c|c|c|c|c|c|c|}
\hline & \multicolumn{2}{|c|}{ Model (1) } & \multicolumn{4}{|c|}{ Model (2) } \\
\hline Variable & $\boldsymbol{\beta}$ & t & Sig. & $\beta$ & $\mathbf{t}$ & Sig. \\
\hline Constant & 0.464 & 1.045 & 0.297 & 0.480 & 1.079 & 0.060 \\
\hline T-Score & -0.158 & -2.570 & 0.011 & 0.020 & 0.074 & 0.0941 \\
\hline BODScore & -0.078 & -1.263 & 0.021 & -0.146 & -1.248 & 0.0213 \\
\hline TScore*BODScore & & & & -0.190 & -0.684 & 0.0495 \\
\hline Size & 0.022 & 0.330 & 0.742 & 0.029 & 0.432 & 0.666 \\
\hline MTB & -0.460 & -6.976 & 0.000 & -0.450 & -6.643 & 0.000 \\
\hline Lev & 0.536 & 5.104 & 0.000 & 0.556 & 5.096 & 0.000 \\
\hline $\mathbf{D} / \mathbf{A}$ & -0.277 & -2.758 & 0.006 & -0.288 & -2.829 & 0.005 \\
\hline $\mathbf{N}$ & & 286 & & & 286 & \\
\hline R-Sq & & 0.252 & & & 0.256 & \\
\hline $\mathbf{F}$ & & 12.070 & & & 10.387 & \\
\hline P-value & & 0.000 & & & 0.000 & \\
\hline
\end{tabular}

It should be noted first that number of More Transparent firms-observations appears to be 286 out of 592 , or $48 \%$ of the sample shows higher levels of Transparency.

Table (6) shows that both models are significant (zero P-values) in expressing the relationship between dependent and independent variables. Explanatory power of the two models is much greater than that of full sample regression in Table (5), where R-sq turns out to be 6\%. In Model (1), T-Score reports a negative significant coefficient $(-0.158,0.011)$. This reveals that higher levels of transparency have the effect of lowering COC, which contradicts results of fundamental analysis. Thus, the first hypothesis is Accepted for More Transparent firms; where transparency lowers COC. Moreover, BOD-Score shows a negative significant coefficient $(-0.078,0.021)$, implying the positive impact of BOD governance in lowering COC. This outcome confirms the 
fundamental results, motivates the Acceptance of the second hypothesis for More Transparent firms.

Regarding the interaction effect, Model (2)'s outcomes contradict fundamental result, where interaction term turns out to negative and significant ($0.19,0.04)$, implying the Acceptance of the third hypothesis for More Transparent firms. This entails that at higher levels of transparency, BOD governance moderates, in a complementary way, the relationship between transparency and COC.

Therefore, for More Transparent firms, evidence provided implies that the two corporate governance mechanisms under investigation, transparency and BOD structure, have a positive impact of pushing down COC. Additionally, BOD governance complements the relationship between transparency and COC. In other words, in highly transparent firms, BOD governance incrementally supports transparency in lowering COC.

\section{2) Less Transparent Firms:}

\section{Table (7)}

Results of Regression Analysis for the effect of Transparency and

BOD Structure on COC For Less Transparent Firms

\begin{tabular}{|c|c|c|c|c|c|c|}
\hline \multicolumn{4}{|c|}{ Model (1) } & \multicolumn{3}{|c|}{ Todel (2) } \\
\hline Variable & $\beta$ & $\mathbf{t}$ & Sig. & $\beta$ & $\mathbf{t}$ & Sig. \\
\hline Constant & 1.621 & 2.128 & 0.034 & 1.484 & 1.894 & 0.060 \\
\hline T-Score & 0.027 & 0.403 & 0.0688 & 0.143 & 0.616 & 0.0539 \\
\hline BODScore & -0.061 & -0.819 & 0.0414 & -0.032 & -0.226 & 0.0821 \\
\hline TScore*BODScore & & & & -0.205 & -0.763 & 0.0446 \\
\hline Size & -0.106 & -1.398 & 0.163 & -0.108 & -1.415 & 0.157 \\
\hline MTB & -0.185 & -2.562 & 0.011 & -0.193 & -2.641 & 0.009 \\
\hline Lev & 0.233 & 2.854 & 0.005 & 0.260 & 2.919 & 0.004 \\
\hline $\mathbf{D} / \mathbf{A}$ & 0.015 & 0.208 & 0.835 & 0.009 & -0.115 & 0.909 \\
\hline $\mathbf{N}$ & \multicolumn{3}{|c|}{306} & \multicolumn{3}{|c|}{306} \\
\hline R-Sq & \multicolumn{3}{|c|}{0.065} & \multicolumn{3}{|c|}{0.069} \\
\hline $\mathbf{F}$ & \multicolumn{3}{|c|}{2.502} & \multicolumn{3}{|c|}{2.223} \\
\hline P-value & \multicolumn{3}{|c|}{0.023} & \multicolumn{3}{|c|}{0.034} \\
\hline
\end{tabular}

109

Vol.2, No.1, Part 1., Jan. 2021 


\section{Dr. Mawaheb Abdel-Aziz Ismail}

Table (7) presents the results of regression relating transparency and BOD structure to COC for less transparent firms under the two models. Outcomes of Model (1) point to positive insignificant coefficient $(0.027,0.068)$ for T-Score, indicating a passive role for lower levels of transparency in decreasing COC. This confirms the fundamental analysis result, and implies the Rejection of first hypothesis for Less Transparent firms. Also, the fundamental analysis implication for the second hypothesis remains valid. Coefficient of BOD-Score appears negative and significant $(-0.061,0.04)$, denoting constructive role of BOD governance in lowering COC in Less transparent firms. Again, this verifies the fundamental analysis result, and implies the Acceptance of second hypothesis for Less Transparent firms.

With respect to Model (2), the negative significant coefficient of interaction term T-Score*BOD-Score $(-0.205,0.044)$, indicating that the two corporate governance mechanisms can be perceived as complements. This implies the Acceptance of third hypothesis predicting an interaction effect between transparency and BOD structure, which contradicts inference of fundamental analysis regarding the third hypothesis.

Overall, for Less Transparent firms, evidence provided suggests that, as opposed to transparency, BOD structure has the potential of lowering COC. Additionally, BOD governance can moderate or compensate for the adverse effect of transparency on COC.

Results reached from the above analysis contradict evidence provided by Upadhyay and Sriram (2011), who uncover a substitution relationship between board size and transparency. They suggest that the positive effect of board size on COC is largely offset by transparency, implying that investors in highly transparent firms do not benefit from board governance.

17.

Vol.2, No.1, Part 1., Jan. 2021 


\section{2- Differential Impact of BOD Governance Levels on COC:}

Following the same previous procedures, firm-year observations are split around the median of BOD-Score (2) into:

-Well-governed BOD firms; whose BOD-Score is greater than the median, and -Poorly-governed BOD firms; whose BOD-Score is less than or equal the median.

Tables (8) and (9) illustrate the regression outcomes for the two sub-groups under the two models.

1) Well-governed BOD Firms:

Table (8)

Results of Regression Analysis for the effect of Transparency and BOD Structure on COC For Well-governed BOD Firms

\begin{tabular}{|c|c|c|c|c|c|c|}
\hline \multicolumn{3}{|c|}{ Model (1) } & \multicolumn{4}{|c|}{ Model (2) } \\
\hline Variable & $\boldsymbol{\beta}$ & $\mathbf{t}$ & Sig. & $\beta$ & $\mathbf{t}$ & Sig. \\
\hline Constant & 0.174 & 0.517 & 0.606 & 0.139 & 0.409 & 0.060 \\
\hline T-Score & -0.04 & -0.563 & 0.574 & 0.451 & 0.881 & 0.380 \\
\hline BODScore & -0.219 & -3.265 & 0.001 & -0.215 & -3.192 & 0.002 \\
\hline TScore*BODScore & & & & -0.495 & -0.968 & 0.0334 \\
\hline Size & 0.195 & 2.342 & 0.020 & 0.202 & 2.418 & 0.017 \\
\hline МТВ & -0.275 & -4.214 & 0.000 & -0.270 & -4.135 & 0.000 \\
\hline Lev & 0.355 & 4.248 & 0.000 & 0.342 & 4.040 & 0.000 \\
\hline D/A & 0.104 & 1.433 & 0.154 & 0.104 & 1.428 & 0.155 \\
\hline $\mathbf{N}$ & & 217 & & & 217 & \\
\hline R-Sq & & 0.352 & & & 0.358 & \\
\hline $\mathbf{F}$ & & 14.047 & & & 12.169 & \\
\hline P-value & & 0.000 & & & 0.000 & \\
\hline
\end{tabular}




\section{Dr. Mawaheb Abdel-Aziz Ismail}

The splitting process indicates that 217 firm-observations are Wellgoverned BOD firms, representing only $37 \%$ of the whole sample. Table (8) documents the significance of the two models (zero P-values) in expressing the relationship between dependent and independent variables. The value of $\mathrm{R}-\mathrm{Sq}$ in the two models denotes the $35 \%$ of variations in COC can be explained through variations in independent variables included in the regression. In Model (1), TScore reports a negative insignificant coefficient $(-0.04,0.574)$. This implies that transparency has insignificant effect on lowering $\mathrm{COC}$, which confirms results of fundamental analysis. Thus, the first hypothesis is Rejected for Well-governed BOD firms. Moreover, BOD-Score shows a negative significant coefficient ($0.219,0.001)$, implying the strong impact of BOD governance in lowering COC. This outcome confirms the fundamental results, promoting the Acceptance of the second hypothesis for Well-governed BOD firms.

Concerning the interaction effect, Model (2)'s outcomes contradict fundamental result, where interaction term turns out to negative and significant (0.495, 0.03), implying the Acceptance of the third hypothesis for Well-governed BOD firms. This entails that at higher levels of BOD governance, transparency complements the relationship between BOD structure and COC.

Therefore, for well-governed BOD firms, results imply that BOD structure has a positive role in lowering COC, while transparency fails to show such impact. Moreover, BOD governance moderates the relationship between BOD structure and COC. 
2) Poorly-governed BOD Firms:

\section{Table (9)}

Results of Regression Analysis for the effect of Transparency and BOD Structure on COC For Poorly-governed BOD Firms

\begin{tabular}{|c|c|c|c|c|c|c|}
\hline \multicolumn{4}{|c|}{ Model (1) } & \multicolumn{3}{|c|}{ Model (2) } \\
\hline Variable & $\beta$ & $\mathbf{t}$ & Sig. & $\beta$ & $\mathbf{t}$ & Sig. \\
\hline Constant & 1.045 & 1.315 & 0.190 & 1.081 & 1.345 & 0.180 \\
\hline T-Score & 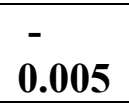 & -0.085 & 0.932 & 0.075 & 0.294 & 0.769 \\
\hline BODScore & 0.114 & 1.635 & 0.103 & 0.112 & 1.595 & 0.112 \\
\hline TScore*BODScore & & & & -0.081 & -0.323 & 0.747 \\
\hline Size & -0.081 & -1.217 & 0.225 & -0.083 & -1.245 & 0.214 \\
\hline MTB & -0.168 & -2.482 & 0.014 & -0.170 & -2.498 & 0.013 \\
\hline Lev & 0.267 & 3.080 & 0.002 & 0.270 & 3.091 & 0.002 \\
\hline $\mathbf{D} / \mathbf{A}$ & -0.017 & -0.211 & 0.8 & -0.019 & -0.231 & 0.818 \\
\hline $\mathbf{N}$ & \multicolumn{3}{|c|}{375} & \multicolumn{3}{|c|}{375} \\
\hline R-Sq & \multicolumn{3}{|c|}{0.081} & \multicolumn{3}{|c|}{0.087} \\
\hline $\mathbf{F}$ & \multicolumn{3}{|c|}{4.033} & \multicolumn{3}{|c|}{3.460} \\
\hline P-value & \multicolumn{3}{|c|}{0.001} & \multicolumn{3}{|c|}{0.001} \\
\hline
\end{tabular}

Table (9) presents the results of regression relating transparency and BOD structure to COC for poorly-governed BOD firms under the two models. In fact, neither Model (1) nor Model (2) shows any significant coefficients, implying the Rejection of the three study hypotheses at 5\% significance level. This entails that at lower levels of BOD governance, both transparency and BOD structure has no impact on decreasing COC. This reflects the dominance of BOD governance, where powerful BOD can compensate for weakness in another corporate governance mechanism, but the opposite is not true. 
Dr. Mawaheb Abdel-Aziz Ismail

\section{Sensitivity Analysis:}

In an attempt to lend more credence to my results, different assessments are used for dependent variable, COC, an approach followed by many of prior studies (Suchard et al. 2012, Upadhyay and Sriram 2011, and Li 2015). In fundamental analysis, COC is measured based on earnings per share growth deflated by stock price.

As a robustness check, the regression is re-performed using dividends per share (DPS) instead of EPS. Ohlson and Juethner-Nauroth (2005) view the estimating cost of capital has to employ DPS, where expected DPS-sequence serves as the ultimate source of value. Moreover, EPS and DPS must be related to each other to make economic sense. In traditional corporate finance text books (Brealey and Myers 1991), EPS and DPS were assumed to have a fixed relation and same growth rate. In addition, Claus and Thomas (2001) utilize dividends growth in formulating their COC estimation model.

Table (10) presents the outputs of the two models when COC is measured using dividends per share:

Table (10)

Results of Regression Analysis for the effect of Transparency and BOD Structure on COC measured based on Dividends Per Share

\begin{tabular}{|c|c|c|c|c|c|c|}
\hline \multicolumn{3}{|c|}{ Model (1) } & \multicolumn{4}{|c|}{ Model (2) } \\
\hline Variable & B & $\mathbf{t}$ & Sig. & $\boldsymbol{\beta}$ & $\mathbf{t}$ & Sig. \\
\hline Constant & 0.783 & 3.141 & 0.002 & 0.776 & 3.096 & 0.002 \\
\hline T-Score & 0.070 & 0.155 & 0.0877 & 0.048 & 0.343 & 0.0731 \\
\hline BODScore & -0.148 & -2.966 & 0.003 & -0.149 & -2.971 & 0.003 \\
\hline TScore*BODScore & & & & -0.044 & -0.309 & $\mathbf{0 . 0 7 5 7}$ \\
\hline Size & -0.089 & -1.687 & 0.092 & -0.087 & -1.644 & 0.101 \\
\hline МTB & -0.243 & -4.913 & 0.000 & -0.244 & -4.916 & 0.000 \\
\hline Lev & 0.167 & 2.864 & 0.004 & 0.167 & 2.868 & 0.004 \\
\hline $\mathbf{D} / \mathbf{A}$ & -0.047 & -0.878 & 0.380 & -0.045 & -0.845 & 0.399 \\
\hline $\mathbf{N}$ & & 592 & & & 592 & \\
\hline R-Sq & & 0.063 & & & 0.069 & \\
\hline $\mathbf{F}$ & & 5.377 & & & 4.613 & \\
\hline P-value & & 0.000 & & & 0.000 & \\
\hline
\end{tabular}

$17 \varepsilon$

Vol.2, No.1, Part 1., Jan. 2021 


\section{Dr. Mawaheb Abdel-Aziz Ismail}

Results in Table (10) confirm results of fundamental analysis. T-Score in Model (1) shows a positive insignificant coefficient $(0.07,0.08)$, implying the Rejection of first hypothesis, where transparency has no effect on lowering COC measured by DPS. BOD-Score appears negative and significant $(-0.148,0.003)$. This supports the positive impact of BOD governance in lowering COC, verifying fundamental analysis, and Accepts the second hypothesis. Model (2)'s outcomes lead to the Rejection of third hypothesis, where no joint impact appears to exist between transparency and BOD governance. This corresponds fundamental analysis's outcomes.

The above evidence agrees with Bhattacharya et al. (2003) implication that earnings-based COC and dividends-based COC reach almost same results.

\section{V.SUMMARY AND CONCLUSION}

This paper belongs to the extended line of literature examining effect of corporate governance mechanisms on firm financial aspects. I investigate the impact of transparency and BOD structure on cost of equity capital for a sample of 592 firm-year observations from 2010 to 2017. Research hypotheses are premised on the established argument that well governed corporations enjoy greater access to discounted sources of finance, and thus, predict a negative significant association between transparent well-governed BOD firms and COC.

Cost of equity capital is measured using PEG model emphasizing earnings growth valuation. Transparency is perceived as a confirmatory factor combining two market-based earnings attributes; timeliness and conservatism. Timeliness is assessed as the explanatory power of the reverse regression of earnings on returns. Whereas conservatism is the ratio of slope coefficients on negative returns to slope coefficients on positive returns. For BOD structure, a summary measure is formed of summing up four indicator variables, denoting board size, independence, audit committee, and duality. Four control variables were included in the analysis in order to account for risk-related characteristics; firm size, market-to-book ratio, leverage, and debt to assets ratio.

170

Vol.2, No.1, Part 1., Jan. 2021 


\section{Dr. Mawaheb Abdel-Aziz Ismail}

The study hypothesizes that both transparency and BOD governance would exert a downward pressure on COC. Moreover, they would interact together to moderate their relationship with COC.

In the fundamental analysis, two models are employed; the first model to detect the separate effect of independent variables, and the second model to detect the interaction effect of independent variables on COC. An additional analysis is performed involving classifying sample firms according to: transparency levels (more- and less-transparent firms), and BOD governance levels (well-and poorlygoverned firms) to trace the impact of differential levels of independent variables on COC.

Sensitivity analysis uses different measure for assessing dependent variable. COC is assessed based on the dividends growth valuation. That is, instead of using earnings per share, dividends per share is used to calculate COC.

\section{Conclusions:}

Results of fundamental analysis imply the rejection of the first hypothesis predicting a negative significant impact of transparency on COC. Moreover, Results of sensitivity analysis confirms the fundamental tests and rejects the first hypothesis of transparency positive role in lowering COC. Nevertheless, relying on evidence provided by differential analysis, this hypothesis has been proven valid only for more-transparent firms, meaning that only higher levels of transparency has the potential of lowering COC. This entails that firms seeking lower COC should devote considerable efforts towards reaching highest levels of transparency.

It's worth mentioning that same findings were reached by a number of studies, such as Givoly and Hayn (2000, 2002), Easley et al. (2002), Francis et al. (2004), Cheng and Liu (2006), and Leuz and Wysocki (2008), where all reject the negative association between transparency and cost of capital. Nevertheless, study's results contradict those reached by Chan et al. (2009), Garcia Lara et al. (2011), Li (2015), and Khalifa and Othman (2015), where all support a negative relationship between conservatism and COC.

Vol.2, No.1, Part 1., Jan. 2021 


\section{Dr. Mawaheb Abdel-Aziz Ismail}

The second hypothesis predicts a negative significant association between BOD structure and COC. This hypothesis was accepted on all analyses, except for poorly-governed BOD firms, where firms showing lower levels of BOD governance fail to impact COC. This result agrees with those of Reverte (2009), Mazzotta and Veltri (2014), Suchard et al. (2012), and Upadhyay and Sriram (2011); where all suggest that well-structured BOD has the effect of lowering COC.

The third hypothesis predicts a joint impact of transparency and BOD structure. The hypothesis has been rejected by fundamental and sensitivity tests. However, differential analyses provide expressive implications, where interaction appears to exist at lower levels of transparency and higher levels of BOD governance. Stated differently, for less-transparent firms, BOD governance compensates for weakness in transparency, and moderate the relationship between transparency and COC. Also, for well-governed BOD firms, higher levels of governance appear to offset the adverse effect of transparency on COC. Provided evidence agrees with findings reached by Upadhyay and Sriram (2011); who suggest that the impact of board size on COC is conditional on corporate information environment.

Research results can be interpreted as follows; first, even though transparency is a core dimension in corporate governance guidelines, evidence reveals its passive impact on an important financial aspect, COC. Egyptian listed companies are required by law to prepare and submit annual reports including financial and nonfinancial information, along with auditor's opinion. Financial statements are prepared and audited in compliance with the Egyptian Accounting and Auditing Standards, which largely emphasize the great importance of transparency and disclosure. Therefore, it seems that the problem lies in monitoring of compliance, not in the laws and legislations themselves.

Second, results on BOD structure reveal the dominant role of BOD in affecting firms' financial aspects. BOD structure has the potential of lowering COC, even at 


\section{Dr. Mawaheb Abdel-Aziz Ismail}

lower transparency levels. Investors' required rate of return appears to be much influenced by board's characteristics, including size, independence, audit committee, and duality.

Third, on absolute terms, no integration exists among different corporate governance mechanisms, where BOD structure fails to moderate the relationship between transparency and $\mathrm{COC}$, except for lower levels of transparency and higher levels of BOD governance. It's noteworthy that the effectiveness of one corporate governance mechanism is more likely to depend on other corporate governance tools in action (Wahba 2015).

This paper makes important contributions to the literature, first; it adds to the existing research addressing the impact of corporate governance tools on financial performance, where it provides evidence supporting the constructive role of well-governed BOD in lowering COC. Second, it extends evidence provided from Egyptian Stock Market on corporate governance impact on different aspects, such as financial distress (Shahwan 2015), debt and firm performance (Wahba 2015), and corporate finance (Elsayed 2011). Third, this paper focuses on two corporate governance tools; and thus provides deeper analysis. Prior studies (e.g., Demsetz and Villalonga 2001, and Dulewicz and Herbert 2003) focusing only on a single corporate governance standard in isolation fail to link such single tool to firm performance.

\section{Implications:}

Evidence provided has significant implications. First, for listed companies, careful attention and considerable efforts must be devoted for enhancing BOD governance, for its impact on firms' access to less costly sources of finance. Efforts should be directed towards enhancing the quality of disclosed information.

Second, for Egyptian Stock Exchange supervisors, more efforts should be exerted to enhance transparency. While monitoring compliance with reporting 


\section{Dr. Mawaheb Abdel-Aziz Ismail}

obligations seems to be in place, this monitoring effort needs to be more extensive to ensure a better quality of transparency and disclosure, especially of non-financial information.

Third, for corporate governance regulators, the approach adopted by the Egyptian corporate governance code should be revised. The code applies "comply or explain" approach, where companies are recommended to comply with the prescribed rules, or to explain the reasons for non-compliance. This means that no mandatory adoption is required. The report of European Bank for reconstruction and Development (2017) documents that in 2014, only two out of ten largest listed companies provided a "comply or explain" statement with the annual reports. Moreover, such statements are merely declaratory and not much informative.

Another point to be emphasized is the integration missed among corporate governance mechanisms. Regulators should investigate and reach how to achieve coordination, so that corporate governance objectives are attained.

\section{Future Research:}

Promising future research areas could place emphasis on employing more dimensions of corporate governance. Researchers could construct a corporate governance index assigning various weights for different components. Evaluating BOD features may extend to include qualifications, other than ones under investigation. For the cost of capital, further tests could consider other models to measure COC, or could rely on weighted average COC. Also, cost of debt could be analyzed in relation to corporate governance standards. 


\section{Dr. Mawaheb Abdel-Aziz Ismail}

\section{References:}

Ahmed, A. S., \& Duellman, S. 2007. Evidence on the role of accounting conservatism in corporate governance. Journal of Accounting and Economics 43: 411-437.

Anderson, R. C., \& Reeb, D. M. 2004. Board composition: Balancing family influence in S\&P 500 firms. Administrative Science Quarterly 49(2): 209237.

Anderson, R.C., S. A. Mansi and D. M. Reeb. 2004. Board Characteristics, Accounting Report Integrity, and Cost of Debt. Journal of Accounting and Economics 37: 315-342.

Ashbaugh-Skaife, H., Collins, D., Lafond, R. 2004. Corporate governance and the cost of equity capital. Working Paper, available at SSRN: http://ssrn.com/abstract=639681.

Ball, R., \& Shivakumar, L. (2005). Earnings quality in UK private firms: Comparative loss recognition timeliness. Journal of Accounting and Economics 39: 83-128.

Ball, R., S. Kothari, and A. Robin. 2000. The Effect of International Institutional Factors on Properties of Accounting Earnings. Journal of Accounting and Economics 29: 1-51.

Basu, S. (1997). The conservatism principle and the asymmetric timeliness of earnings. Journal of Accounting and Economics 24: 3-37.

Battacharya, U., Daouk, H., and Welker, M. 2003. The world price of earnings opacity. The Accounting Review 78(3): 641-678.

IV.

Vol.2, No.1, Part 1., Jan. 2021 


\section{Dr. Mawaheb Abdel-Aziz Ismail}

Beaver, W. H., and Ryan, S. G. 2005. Conditional and unconditional conservatism: concepts and modeling. Review of Accounting Studies 10: 269-309.

Beekes, W., Pope, P. F., and Young, S. 2004. The link between earnings timeliness, earnings conservatism and board composition: Evidence from the UK. Corporate Governance 12(1): 47-51.

Botoson, C., and M. Plumlee. 2005. Assessing Alternative Proxies for the Expected Risk Premium. The Accounting Review 80: 21-53.

Bowen, R., S. Rajagopal and M. Venkatachalam. 2008. Accounting Discretion, Corporate Governance and Firm Performance. Contemporary Accounting Research 25: 351-405.

Bozcuk, A. E. 2011. Performance effects of outside directors on corporate boards. International Journal of Business and Social Science 2(20): 80-84.

Brealey, R. A., and Myers, S. C. 1991. The dividend controversy.

Brealey, R. A., Myes, S. C., Allen, F., and Sandri, S. 2007. Principles of Corporate Finance. Milan: McGraw-Hill.

Brickley, J., Coles, J., and Terry, R. 1994. Outside directors and the adoption of poison pills. Journal of Financial Economics. 35(3): 371-390.

Brown, J.R., Falaschetti, D. and Orlando, M.J., 2008. Auditor independence and earnings quality: Evidence for market discipline vs. Sarbanes-Oxley proscriptions. FSU College of Law. Law and Economics Paper: 7-33.

Brunnige, O., Nordqvist, M., and Wiklund, J. 2007. Corporate governance and strategic change in SMEs: The effects of ownership, board composition, and top management teams. Small Business Economics 29: 295-308.

IVI

Vol.2, No.1, Part 1., Jan. 2021 


\section{Dr. Mawaheb Abdel-Aziz Ismail}

Bushman, R., Q. Chen, E. Engel, and A. Smith. 2002. Financial accounting information, organizational complexity and corporate governance systems. Journal of Accounting and Economics, 37(2), 167-201.

Byun, H., Kwak, S., and Hwang, L. 2008. The implied cost of equity capital and corporate governance practices. Asia-Pacific Journal of Financial Studies 37(1): 139-184.

Chan, A. L. C., Lin, S. W., and Strong, N. 2009. Accounting conservatism and the cost of equity capital: UK evidence. Managerial Finance 35 (4): 325-345.

Chen, F., Jorgensen, B., \& Yoo, Y. K. 2004. Implied cost of equity capital in earnings based valuation: International evidence. Accounting and Business Research, 34, 323-344.

Chen, K. C. W., Chen, Z., Wei, K. C. J. 2003. Disclosure, corporate governance and the cost of equity capital: Evidence from Asia's emerging markets. Proceedings of the 3rd Asian Corporate Governance conference, Korea University and the Hong Kong University of Science and Technology.

Chen, K., Chen, Z. and K.Wei, 2009, "Legal Protection of Investors, Corporate Governance and the Cost of Equity Capital", Journal of Corporate Finance 15: 273-289.

Chen, Q., T. Hemmer and Y. Zhang. 2007. On the Relation between Conditional Conservatism in Accounting Standards and Incentives for Earnings Management. Journal of Accounting Research 45: 541-565.

Cheng, S. (2008), 'Board Size and the Variability of Corporate Performance', Journal of Financial Economics 87: 157-76. 


\section{Dr. Mawaheb Abdel-Aziz Ismail}

Cheng, A., and C., Liu. 2006. Value relevance of earnings for conservative and non-conservative firms. Working paper. University of Houston.

Claus, J. and J. Thomas. 2001. Equity Premia as Low as three Percent? Evidence from Analysts' Earnings Forecasts for Domestic and International Stock Markets. Journal of Finance 56: 1629-1666.

Collins, D., E. Maydew, and I. Weiss. 1997. Changes in the value-relevance of earnings and book values over the past forty years. Journal of Accounting and Economics 24: 39-67.

Daily, C., Dalton, D., and Cannella, A. 2003. Corporate governance: Decades of dialogue and data. Academy of Management Review 28(3): 371-382.

Dalton, D. R., Daily, C. M., Ellstrand, A. E., and Johnson, J. L. 1998. Meta-analytic reviews of board composition, leadership structure, and financial performance. Strategic Management Journal 19: 269-290.

Daouk, H., C. Lee and D. T. Ng. 2006. Capital Market Governance: Do Securities Laws Affect Market Performance?. Journal of Corporate Finance 12: $560-593$.

Demsetz, H., \& Villalonga, B. 2001. Ownership structure and corporate performance. Working Paper. University of California.

Dodo, A. 2017. Corporate collapse and the role of audit committees: A case study of Lehman Brothers. World Journal of Social Sciences 7 (1): 19-29.

Dulewicz, V., and Herbert, P. 2003. Does the composition and practice of UK boards bear any relationship to the performance of listed companies? Working Paper. Henley Management College.

IVT

Vol.2, No.1, Part 1., Jan. 2021 


\section{Dr. Mawaheb Abdel-Aziz Ismail}

Dunn, K.A. and Mayhew, B.W., 2004. Audit Industry Specialization and Client Disclosure Quality. Review of Accounting Studies 9 (2): 35-58.

Durnev, A. and E. Kim, 2005, To Steal or not to Steal: Firm Attributes, Legal Environment and Valuation. Journal of Finance 60: 1461-1493.

Dye, R. 2001. An evaluation of 'essays on disclosure' and the disclosure literature in accounting. Journal of Accounting and Economics 32: 181-232.

Easley, D. and M. O'Hara. 2004. Information and the Cost of Capital. Journal of Finance 59: 1553-1583

Easley, D., S. Hvidkjaer, and M. O'Hara. 2002. Is information risk a determinant of assets returns. Journal of Finance 57: 2185-2221.

Easton, P. 2004. PE Ratios, PEG Ratios, and Estimating the Implied Expected Rate of Return on Equity Capital. The Accounting Review 79 (2004): 73-95.

Easton, P., and S. Monahan. 2005. An Evaluation of the Reliability of Accounting Based Measures of Expected Returns: A Measurement Error Perspective. The Accounting Review 80: 501-538.

Elsayed, K. 2007. Does CEO duality really affect corporate performance? Corporate Governance: An International Review 15(6): 1203-1214.

Elsayed, K. 2011, Board size and corporate performance: the missing role of board leadership structure. Journal of Management and Governance 15 (3): 415 446.

IV

Vol.2, No.1, Part 1., Jan. 2021 
Fama, E., and K. French. 1993. Common Risk Factors in the Returns on Stocks and Bonds. Journal of Financial Economics 33: 3-56.

Fama, E., and K. French. 1997. Industry Costs of Equity. Journal of Financial Economics 43: 153-93.

Fama, E. F., and Jensen, M. C. 1983. The separation of ownership and control. Journal of Law and Economics, 26(2): 301-325.

Florackis, C. 2008. Agency costs and corporate governance mechanisms: Evidence from UK firms. International Journal of Managerial Finance 4 (1): 37-59.

Francis, J., and Schipper, K. 1999. Have financial statements lost their relevance?. Journal of accounting Research, 37(2): 319-352.

Francis, J., LaFond, R., Olsson, P., and Schipper, K. 2004. Cost of equity and earnings attributes. The Accounting Review 79(4): 967-1010.

Garci'a Lara, J., Garcı'a Osma, B., \& Penalva, F. 2009a. Accounting conservatism and corporate governance. Review of Accounting Studies 14(1): 161-201.

Garcia Lara, J. M., B. Garcia Osma and F. Penalva. 2011. Conditional Conservatism and the Cost of Capital', Review of Accounting Studies, Vol. 16, pp. 247-271.

Gebhardt, W., C. Lee and B. Swaminathan. 2001. Toward an Implied Cost of Capital. Journal of Accounting Research 39: 135-76.

Gietzmann, M. and J. Ireland. 2005. Cost of Capital, Strategic Disclosure and Accounting Choice. Journal of Business Finance \& Accounting. 32: 599634.

IVo

Vol.2, No.1, Part 1., Jan. 2021 


\section{Dr. Mawaheb Abdel-Aziz Ismail}

Givoly, D., and Hayn, C. 2000. The changing time-series properties of earnings, cash flows and accruals: Has financial reporting become more conservative? Journal of Accounting and Economics. 29: 287-320.

Givoly, D., and Hayn, C. 2002. Rising conservatism: Implications for financial analysis. Financial Analysts Journal 58(1): 56-74.

Guay, W., and Verrecchia, R. E. 2007. Conservative disclosure. Working paper. University of Pennsylvania.

Hail, L. and C. Leuz. 2006. International Differences in the Cost of Capital: Do Legal Institutional and Securities Regulation Matter? Journal of Accounting Research 44: 485-531.

Hair, J.F., Tatham, R.L., Anderson, R.E. and Black, W. 2006. Multivariate Data Analysis, Pearson Prentice Hall, Upper Saddle River, NJ 6.

Jensen, M. 1993.The Modern Industrial Revolution, Exit and the Failure of Internal Control Systems. Journal of Finance 48: 831-880.

Khalifa, M., and Ben Othman, H. 2015. The effect of conservatism on cost of capital: MENA evidence. Applied Economics 47(1): 71-87.

Klein, A. 1998. Firm Performance and Board Committee Structure. Journal of Law and Economics 41: 37-165.

Klein, A. 2006. Audit committee, board of directors' characteristics, and earnings management. Law and Economics Research paper series No. 06-42.

Kline, R.B. 1998. Principles and Practice of Structural Equation Modeling, Guilford, New York, NY. 
LaFond, R., and Watts, R. 2008. The information role of conservatism. The Accounting Review 83: 443-478.

Lambert, R., Leuz, C., and Verrecchia, R. 2007. Accounting information, disclosure, and the cost of capital. Journal of Accounting Research 45(2): $385-420$.

Lambert, R., Leuz, C., and Verrecchia, R. 2008. Information asymmetry, information precision, and the cost of capital. Working paper. University of Pennsylvania.

Lee, E., Walker, M., Christensen, H. 2006. The cost of capital in Europe: An empirical analysis and the preliminary impact of international accounting harmonisation. ACCA Research Report No. 94, London: CAET.

Leuz, C. and P.D. Wysocki. 2008. Economic Consequences of Financial Reporting and Disclosure Regulation: What Have We Learned?. Working Paper (MIT Sloan).

Li, X. 2015. Accounting conservatism and the cost of capital: An international analysis. Journal of Business Finance \& Accounting, 42(5-6): 555-582.

Lin, J., and M. Hwang. 2010. Audit quality, corporate governance, and earnings management: A meta-analysis. International Journal of Auditing 14: 5777 .

Lipton, M. and J. W. Lorsch 1992. A Modest Proposal for Improved Corporate Governance. Business Lawyer 1: 59-77.

IVV

Vol.2, No.1, Part 1., Jan. 2021 


\section{Dr. Mawaheb Abdel-Aziz Ismail}

Mangena, M., Pike, R., \& Li, J. 2010. Intellectual capital disclosure practices and effects on the cost of equity capital: UK evidence. Edinburgh: The Institute of Chartered Accountants of Scotland.

Mazzotta, R., \& Veltri, S. 2014. The relationship between corporate governance and the cost of equity capital. Evidence from the Italian stock exchange. Journal of Management \& Governance 18(2): 419-448.

Mendez, C. F., \& Garcia, R. A. 2007. The effects of ownership structure and board composition on the audit committee meeting frequency: Spanish evidence. Corporate Governance, 15(5): 909-922.

Mishra, S., \& Mohanty, P. 2014. Corporate governance as a value driver for firm performance: evidence from India. Corporate Governance.

Mitton, T., 2002, “A Cross-Firm Analysis of the Impact of Corporate Governance on

the East Asian Financial Crisis”, Journal of Financial Economics, 64, 215-241.

Nordberg, D. (2010). Corporate governance: Principles and issues. Sage.

Ohlson, J., and B. Juethner-Nauroth. 2005. Expected EPS and EPS Growth as Determinants of Value. Review of Accounting Studies 10: 349-65.

Park, Y. W., \& Shin, H. H. 2004. Board composition and earnings management in Canada. Journal of Corporate Finance 10(3): 431-457.

Patelli, L., \& Prencipe, A. 2007. The relationship between voluntary disclosure and independent directors in the presence of a dominant shareholder. European Accounting Review 16(1): 5-33.

IVA

Vol.2, No.1, Part 1., Jan. 2021 
Peasnell, K., P. Pope and S.Young. 2005. Board Monitoring and Earnings Management: Do Outside Directors Influence Abnormal Accruals? Journal of Business Finance \& Accounting 32: 1311-46.

Penman, S. H., \& Zhang, X. J. 2002. Accounting conservatism, the quality of earnings, and stock returns. The accounting review 77(2): 237-264

Pope, P. F., \& Walker, M. 1999. International differences in the timeliness, conservatism and classification of earnings. Journal of Accounting Research, 37(Supplement): 53-99.

Reverte, C. 2009. Do better governed firms enjoy a lower cost of equity capital? Evidence from Spanish firms. Corporate Governance 9(2): 133-145.

Shahwan, T.M., 2015. The effects of corporate governance on financial performance and financial distress: evidence from Egypt. Corporate Governance 15(5): 641-662.

Shleifer, A. and R. Vishny, 1997, "A Survey of Corporate Governance”, Journal of Finance 52: 737-783.

Solomon, J. (2007). Corporate governance and accountability. John Wiley \& Sons

Suchard, J. A., Pham, P. K., and Zein, J. 2012. Corporate governance and the cost of capital: evidence from Australian firms. Journal of Applied Corporate Finance 24(3): 84-93.

Sulong, Z. and Nor F. 2010. Corporate governance mechanisms and firm valuation in Malaysia listed firms: A panel data analysis. Journal of Modern Accounting and Auditing 6 (1): 1-19. 
Turley, S., \& Zaman, M. 2004. The corporate governance effects of audit committees. Journal of Management and Governance, 8(3), 337-343.

Upadhyay, A., and R. Sriram. 2011. Board size, corporate information environment and cost of capital. Journal of Business Finance \& Accounting 38(9): $1238-1261$.

Virginia, A., K. Eleni, P. Dimitrios, and X. Chrysoula. 2009. The role of financial accounting information in strengthening corporate control mechanisms to alleviate corporate corruption. Working Paper. University of Macedonia, Greece.

Wahba, H. 2015, "The joint effect of board characteristics on financial performance: empirical evidence from Egypt", Review of Accounting and Finance 14 (1): 20-40.

Watts, R. 2003. Conservatism in accounting Part I: Explanations and implications. Accounting Horizons 17(3): 207-221.

Wu, Y. 2000. Honey, I Shrunk the Board. Resource document. University of Chicago.

Yermack, D. 1996. Higher Market Valuation of Companies with a Small Board of Directors. Journal of Financial Economics 40: 185-212.

$1 \wedge$.

Vol.2, No.1, Part 1., Jan. 2021 
الأثر المشترك لثفافية المعلومات وهيكل مجلس الادارة على تكلفة رأس المال: دراسة تطبيقية علئة الثركات المقيدة بالبورصة الادرة المصرية

إعداد

د. مواهب عبد العزيز إسماعيل

مدرس المحاسبة ـ كلبة التجارة - جامعة الإسكندرية

mawaheb.ismail@comm.alexu.eg

$\underline{\text { mawaheb.ismail@gmail.com }}$

يتناول البحث دراسة الأثر المشترك لثفافية المعلومات وهيكل مجلس الادارة على تكلفة رأس المال، وذلك

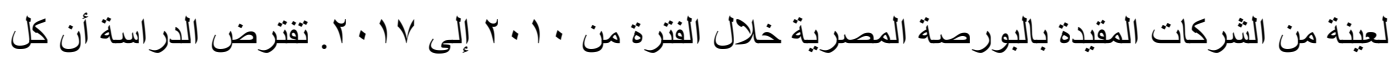
من الثفافية و هيكل مجلس الادارة له تأثثر معنوي على خفض تكلفة رأس المال. كما تتنبأ بوجود أثر مشترك

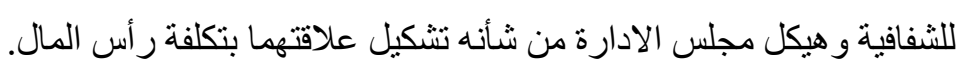

وقد توصل البحث إلى قبول فرض التأثير الموجب لحوكمة مجلس الادارة على خفض تكلفة رأس المال،

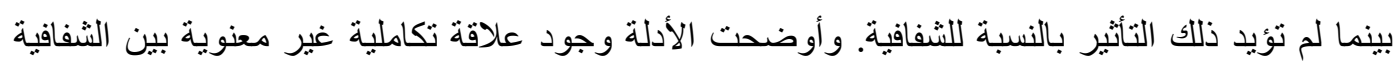
و هيكل مجلس الادارة. وقد أكدت الاختبار ات الاضافية وتحليل الحساسية النتائج السابقة.

الكلمات المفتاحية: تكلفة رأس المال، حوكمة الثركات، الوقتية، التحفظ، الثشافية، حجم مجلس الادارة، استقلالية مجلس الادارة، لجان المر اجعة، ازدو اجية المدير التنفيذي.

Vol.2, No.1, Part 1., Jan. 2021 